\title{
FAKTOR-FAKTOR YANG MEMPENGARUHI KEMISKINAN DI KOTA/KABUPATEN PROVINSI SUMATERA BARAT DENGAN MENGGUNAKAN ANALISIS REGRESI PANEL
}

\author{
AYU ALIFAH, HAZMIRA YOZZA, YUDIANTRI ASDI \\ Program Studi Matematika, \\ Fakultas Matematika dan Ilmu Pengetahuan Alam, Universitas Andalas, \\ Kampus UNAND Limau Manis Padang, Indonesia. \\ email : ayualifah56@gmail.com,hazmirayozza@sci.unand.ac.id,yudiantriasdi@sci.unand.ac.id
}

\begin{abstract}
Abstrak. Kemiskinan diartikan sebagai suatu keadaan dimana taraf hidup manusia berada pada keadaan serba kekurangan dan tidak mampu untuk memenuhi kebutuhan dasar. Salah satu cara untuk mengukur kemiskinan di suatu daerah adalah dengan menggunakan indikator persentase penduduk miskin di daerah tersebut. Provinsi Sumatera Barat merupakan salah satu daerah yang masih memiliki penduduk miskin dengan persentase yang cukup besar. Pemerintah Sumatera Barat berusaha untuk menekan persentase kemiskinan dari berbagai aspek yang terkait dengan faktor-faktor yang diperkirakan mempengaruhi angka kemiskinan. Data mengenai persentase penduduk miskin serta faktor-faktor yang diduga mempengaruhinya dikumpulkan Badan Pusat Statistik untuk semua daerah secara berkala, sehingga untuk semua daerah secara berkala, sehingga untuk masing-masing daerah tersedia data dari tahun ke tahun. Data pengamatan yang dikumpulkan untuk beberapa objek pengamatan dan untuk beberapa waktu itu disebut data panel. Penelitian ini bertujuan untuk menganalisis faktor-faktor yang mempengaruhi kemiskinan di Provinsi Sumatera Barat pada tahun 2015-2017 dengan menggunakan Analisis Regresi Panel.

Pada penelitian ini diperoleh metode yang tepat digunakan adalah random effect model dengan faktor yang signifikan mempengaruhi persentase kemiskinan yaitu penduduk yang tamat SMA. Dari hasil penelitian ini, semakin tinggi persentase penduduk yang tamat SMA, maka semakin rendah persentase penduduk miskin.
\end{abstract}

Kata Kunci: Data Panel, Analisis Regresi Panel, Random effect model

\section{Pendahuluan}

Kemiskinan merupakan masalah utama yang dihadapi pemerintahan di hampir semua negara, termasuk di Indonesia. Kemiskinan juga merupakan salah satu indikator kesejahteraan dimana suatu negara dikatakan sejahtera apabila persentase penduduk miskin di negara tersebut rendah. Kemiskinan dapat diartikan sebagai suatu taraf hidup yang berada pada keadaan serba kekurangan dan tidak mampu untuk

*penulis korespondensi 
memenuhi kebutuhan dasar seperti kebutuhan sandang, pangan, papan, dan lainlain. Kemiskinan menyebabkan banyak anak tidak dapat mengenyam pendidikan yang berkualitas, sulitnya mendapatkan pelayanan kesehatan dan jaminan sosial, serta sulitnya mendapatkan pekerjaan sehingga munculnya pengangguran.

Sebagai sebuah indikator kesejahteraan, pemerintah Sumatera Barat berusaha untuk menekan persentase kemiskinan dari berbagai bidang yang terkait dengan faktor-faktor yang diperkirakan mempengaruhi angka kemiskinan ini. Untuk itu diperlukan suatu analisis yang menduga faktor manakah yang mempengaruhi tingginya persentase kemsikinan secara signifikan di Sumatera Barat berdasarkan data persentase kemiskinan. Salah satu analisis yang dapat digunakan untuk tujuan tersebut adalah analisis regresi. Data mengenai persentase penduduk miskin serta faktor-faktor yang diduga mempengaruhinya dikumpulkan Badan Pusat Statistik untuk semua daerah secara berkala, sehingga untuk masing-masing daerah tersedia data dari tahun ke tahun. Data pengamatan yang dikumpulkan untuk beberapa objek pengamatan dan untuk beberapa waktu itu disebut data panel.

Data panel adalah data yang diambil dari rentang tahun kejadian, yang merupakan gabungan dari data cross section dan data time series. Analisis statistika yang digunakan untuk memodelkan hubungan antara variabel untuk data panel dinamakan Analisis Regresi Data Panel. Data merupakan data cross section karena pengamatan dilakukan terhadap 19 kabupaten/kota di Sumatera Barat dan merupakan data time series karena data tersedia untuk beberapa tahun.

\section{Landasan Teori}

\subsection{Analisis Regresi Linier Berganda}

Analisis regresi linier berganda adalah analisis statistika yang digunakan untuk menganalisis hubungan secara linier antara dua atau lebih variabel prediktor $X_{1}, X_{2},,, X_{k}$ dengan satu variabel respon $Y$. Model analisis regresi berganda dapat dituliskan sebagai berikut

$$
Y_{i}=\beta_{0}+\beta_{1} X_{i 1}+\cdots+\beta_{K} X_{i K}+\varepsilon_{i}
$$

dengan : $Y_{i}$ adalah nilai variabel respon pengamatan ke- $i, \beta_{0}, \beta_{1}, \cdots, \beta_{K}$ adalah parameter regresi, $X_{i 1}, \cdots, X_{i K}$ adalah nilai variabel prediktor pada pengamatan ke- $i, \varepsilon_{i}$ adalah sisaan pengamatan ke- $i, i=1,2, \cdots$, .

Salah satu metode untuk mengestimasi model regresi ini adalah Metode Kuadrat Terkecil (MKT). Dengan metode ini, pendugaan parameter dilakukan dengan meminimumkan jumlah kuadrat sisaan yaitu $\left(\sum_{i=1}^{N} e_{i}^{2}\right)$, sehingga diperoleh

$$
\hat{\beta}=\left(\mathbf{X}^{T} \mathbf{X}\right)^{-1}\left(\mathbf{X}^{T} \mathbf{Y}\right)
$$

Pada analisis regresi linier terdapat koefisien determinasi yang digunakan untuk menilai kebaikan model yang dihasilkan. Nilai $R^{2}$ dapat dihitung dengan

$$
R^{2}=\frac{\sum_{i=1}^{i=N}\left(\hat{y}_{i}-\bar{y}\right)^{2}}{\sum_{i=1}^{i=N}\left(y_{i}-\bar{y}\right)^{2}} .
$$


Pengujian model regresi linier dilakukan untuk mengetahui signifikansi hubungan antara variabel bebas dan variabel terikat. Uji $F$ menguji signifikansi parameter regresi secara bersamaan, dengan kata lain digunakan untuk memastikan bahwa model yang dipilih layak atau tidak untuk mengintepretasikan pengaruh variabel prediktor terhadap variabel respon. Hipotesisnya sebagai berikut.

$$
\begin{aligned}
& H_{0}: \beta_{1}=\beta_{2}=\cdots=\beta_{k}=0, \\
& H_{1}: \text { paling sedikit satu nilai } \beta_{i} \neq 0 \text { dengan } i=1,2, \cdots, k .
\end{aligned}
$$

Statistik uji yang digunakan adalah :

$$
F_{\text {hitung }}=\frac{\left(R^{2}\right)(n-k-1)}{\left(1-R^{2}\right)(k)} .
$$

Apabila $F_{\text {hitung }} \geq F_{\text {tabel }}\left(F_{\alpha, k, N-k-1)}\right.$ maka $H_{0}$ ditolak atau nilai $p$-value $<\alpha$.

Uji $t$ dikenal dengan uji parsial, yaitu untuk menguji bagaimana pengaruh masing-masing variabel prediktor secara sendiri-sendiri terhadap variabel respon. Hipotesis dari pengujian ini adalah [1] :

$$
\begin{aligned}
& H_{0}: \beta_{i}=0, \\
& H_{1}: \beta_{i} \neq 0, i=1,2, \cdots, k .
\end{aligned}
$$

Statistik uji yang digunakan:

$$
t_{\text {hitung }}=\frac{\hat{\beta}_{i}}{\operatorname{se}\left(\hat{\beta}_{i}\right)} .
$$

Jika $\left|t_{\text {hitung }}\right| \geq t_{\text {tabel }}\left(t_{\alpha / 2, N-k}\right)$ maka $H_{0}$ ditolak dengan $N$ adalah jumlah pengamatan dan $k$ banyaknya variabel prediktor.

\subsection{Model Regresi Data Panel}

Analisis regresi data panel adalah analisis regresi yang digunakan untuk struktur data yang merupakan data panel. Secara umum, model regresi panel yaitu : [2]

$$
Y_{i t}=\alpha_{i t}+\beta_{1} X_{1 i t}+\beta_{2} X_{2 i t}+\cdots+\beta_{k} X_{K i t}+u_{i t}
$$

dengan,

$Y_{i t}$ : nilai variabel respon untuk pengamatan $\mathrm{ke}-i$ dan waktu ke $-t$,

$\alpha_{i t}$ : koefisien untuk unit cross section $\mathrm{ke}-i$ dan periode waktu ke $-t$,

$u_{i t}$ : komponen error unit cross section ke $-i$ untuk waktu ke $-t$,

$\beta_{1}, \beta_{2}, \cdots, \beta_{K}$ : koefisien regresi panel dengan $K$ adalah variabel prediktor,

$X_{k i t}$ : nilai pengamatan pada variabel prediktor ke $-k$ untuk unit cross section ke $-i$ pada periode waktu ke $-t$,

$$
\begin{aligned}
& i: 1,2, \cdots, N, \\
& t: 1,2, \cdots, T .
\end{aligned}
$$




\subsection{Model Estimasi Model Regresi Panel}

Dalam melakukan estimasi dengan model regresi panel terdapat tiga pendekatan, yaitu common effect model, fixed effect model, dan random effect model.

\subsubsection{Common Effect Model}

Common effect model mengasumsikan bahwa intersep masing-masing cross section dan waktu adalah sama. Dalam model ini, untuk mengestimasi model data panel digunakan pendekatan teknik kuadrat terkecil. Secara umum, persamaan common effect model dapat dituliskan sebagai berikut : [4]

$$
Y_{i t}=\alpha+\beta_{1} X_{1 i t}+\beta_{2} X_{2 i t}+\cdots+\beta_{k} X_{K i t}+u_{i t} .
$$

\subsubsection{Fixed Effect Model}

Fixed effect model menunjukkan bahwa intersep dari masing-masing unit cross section berbeda, namun intersep untuk unit time series tetap (konstan). Selain itu, model ini juga mengasumsikan bahwa koefisien regresi (slope) tetap antar waktu dan individu [3]. Bentuk umum dari fixed effect model dapat dituliskan sebagai berikut :[2]

$$
Y_{i t}=\alpha_{i}+\beta_{1} X_{1 i t}+\beta_{2} X_{2 i t}+\cdots+\beta_{k} X_{K i t}+u_{i t} .
$$

Untuk mengestimasi data panel fixed effects model digunakan variabel dummy untuk menangkap perbedaan intersep antar individu. Variabel dummy adalah variabel bebas kategorik yang dapat dibentuk menjadi variabel buatan yang mengambil nilai 0 dan 1. Model estimasi ini sering juga disebut dengan teknik Least Squares Dummy Variable $(L S D V)$ [4]. Dengan menggunakan variabel dummy persamaan fixed effect model (2.3) dapat ditulis sebagai berikut :

$$
Y_{i t}=\sum_{j=1}^{N-1} \alpha_{j} D_{j i}+\beta_{1} X_{1 i t}+\beta_{2} X_{2 i t}+\cdots+\beta_{k} X_{k i t}+u_{i t}
$$

dengan $D_{j}$ adalah variabel dummy ke- $j, j=1,2, \cdots, N-1$.

\subsubsection{Random Effect Model}

Estimasi data panel dengan fixed effect model menggunakan teknik variabel dummy. Variabel dummy bisa menghalangi untuk mengetahui model aslinya. Oleh karena itu, estimasi perlu dilakukan dengan menggunakan random effect model. Secara umum persamaan random effect model adalah sebagai berikut [2].

$$
Y_{i t}=\alpha_{i t}+\beta_{1} X_{1 i t}+\beta_{2} X_{2 i t}+\cdots+\beta_{k} X_{K i t}+u_{i t},
$$

dimana, $\alpha_{i t}$ tidaklah bersifat tetap yang diasumsikan sebagai variabel acak jika nilai rata-rata dari intersep ini adalah $\overline{\alpha_{0}}$, maka nilai intersep dari setiap individu dapat ditulis sebagai berikut : [4]

$$
\alpha_{i t}=\overline{\alpha_{0}}+\epsilon_{i}, i=1,2, \cdots, N \text {. }
$$


Sehingga modelnya menjadi: [4]

$$
\begin{aligned}
Y_{i t} & =\overline{\alpha_{0}}+\beta_{1} X_{1 i t}+\beta_{2} X_{2 i t}+\cdots+\beta_{k} X_{K i t}+\epsilon_{i}+u_{i t} \\
& =\overline{\alpha_{0}}+\beta_{1} X_{1 i t}+\beta_{2} X_{2 i t}+\cdots+\beta_{k} X_{K i t}+v_{i t}
\end{aligned}
$$

dengan $v_{i t}=\epsilon_{i}+u_{i t}$.

\subsection{Pengujian Pemilihan Model Regresi Panel}

Uji Chow digunakan untuk menentukan apakah fixed effect model atau common effect model yang lebih tepat digunakan dalam mengestimasi data panel. Misal $\alpha_{i}$ merupakan intersep unit cross section ke-i pada fixed effect model. Hipotesisnya sebagai berikut : [1]

$$
\begin{aligned}
& H_{0}: \alpha_{i}=\alpha \text { untuk semua } i=1,2, \cdots, N, \\
& H_{1}: \text { paling tidak ada satu } \alpha_{i} \neq \alpha, i=1,2, \cdots, N .
\end{aligned}
$$

Statistik uji :

$$
F_{\text {hitung }}=\frac{\left(R S S_{1}-R S S_{2}\right) /(N-1)}{R S S_{2} /(N T-N-K)},
$$

dimana, $R S S_{1}$ : Jumlah kuadrat sisaan untuk common effect model, $R S S_{2}$ : Jumlah kuadrat sisaan untuk fixed effect model.

Jika nilai statistik $F_{\text {hitung }}>F_{N-1, N T-N-K}$ atau $p$-value $<\alpha$ maka tolak $H_{0}$. Ini berarti bahwa, intersep untuk semua unit cross section tidak sama, sehingga untuk mengestimasi persamaan regresi digunakan fixed effect model.

Selanjutnya akan dilakukan Uji Hausman untuk menentukan apakah Fixed Effect Model atau Random Effect Model yang lebih tepat digunakan dalam mengestimasi data panel. Hipotesis uji Hausman adalah sebagai berikut : [1]

$$
\begin{aligned}
& H_{0}: E\left(v_{i t} x_{i t}\right)=0, \\
& H_{1}: E\left(v_{i t} x_{i t}\right) \neq 0
\end{aligned}
$$

Nilai statistik uji Hausman dapat dituliskan sebagai berikut $: X_{K}^{2}=\left(\hat{\boldsymbol{\beta}}_{F E M}-\right.$ $\left.\hat{\boldsymbol{\beta}}_{R E M}\right)^{\prime}\left[\operatorname{var}\left(\hat{\boldsymbol{\beta}}_{F E M}-\hat{\boldsymbol{\beta}}_{R E M}\right)\right]^{-1}\left(\hat{\boldsymbol{\beta}}_{F E M}-\hat{\boldsymbol{\beta}}_{R E M}\right)$

dimana

$\hat{\boldsymbol{\beta}}_{R E M}$ : vektor estimasi parameter random effect model

$\hat{\boldsymbol{\beta}}_{F E M}$ : vektor estimasi parameter fixed effect model.

Jika nilai statistik Hausman lebih besar dari pada nilai kritis statistik chi-square dengan derajat bebas sebanyak jumlah variabel prediktor atau $p$-value $<\alpha$, maka tolak $H_{0}$. Ini berarti bahwa, estimasi yang tepat digunakan adalah fixed effect model.

\section{Pembahasan}

Pada bab ini akan dibahas faktor yang signifikan mempengaruhi kemiskinan serta memilih model terbaik antara model regresi data panel. 

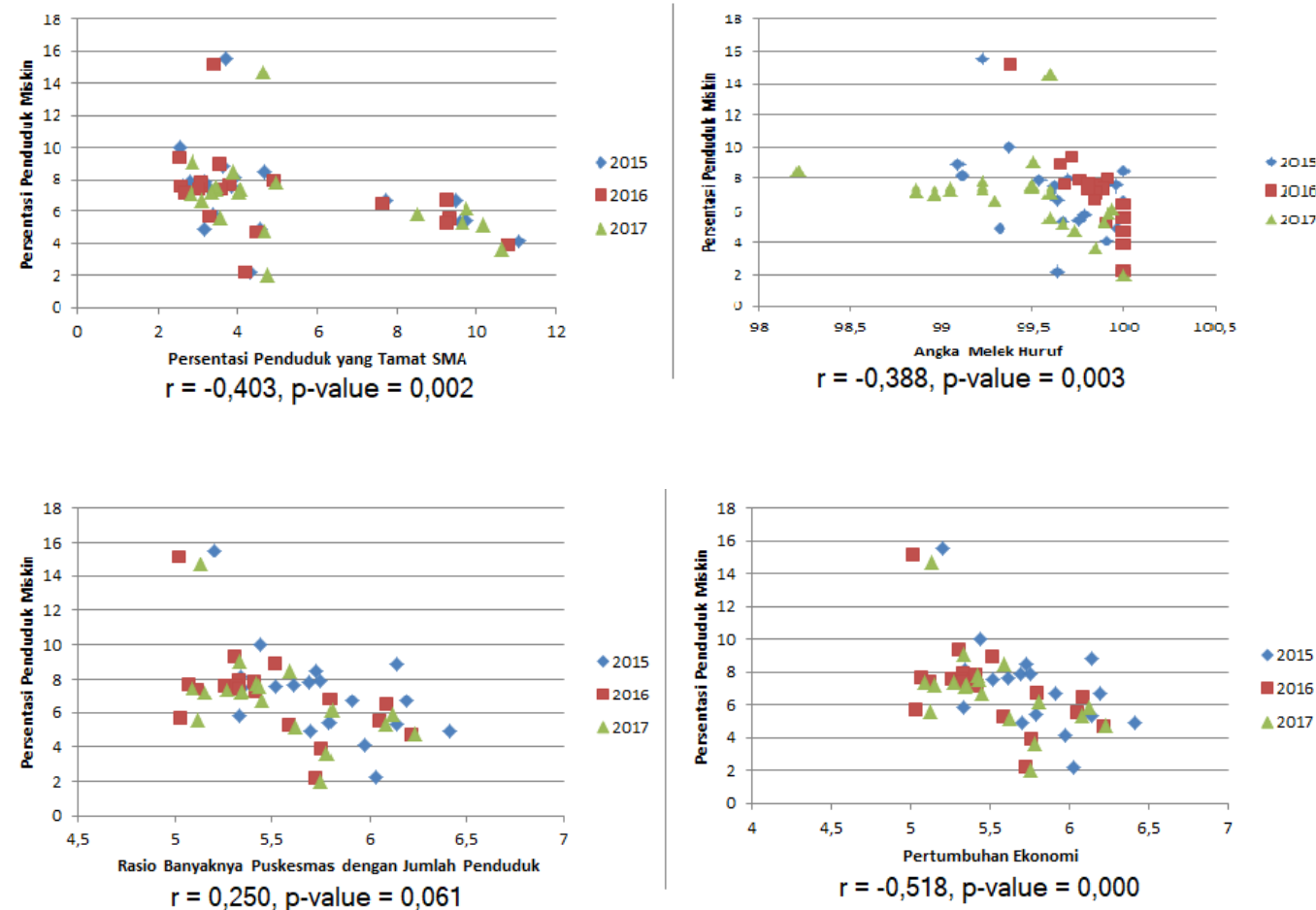

Gambar 1. Diagram pencar persentase penduduk miskin dengan Variabel Prediktor

\subsection{Eksplorasi Data}

Akan disajikan diagram pencar antara persentase penduduk miskin dengan masingmasing variabel prediktor.

Gambar 1(a) memperlihatkan diagram pencar antara persentase penduduk miskin dengan persentase penduduk yang tamat SMA dan adanya hubungan linier negatif antara kedua variabel. Dengan nilai $p$-value tersebut dapat dikatakan bahwa terdapat korelasi yang nyata antara kedua variabel yang berarti bahwa sebagai semakin besar persentase penduduk yang tamat SMA maka semakin rendah persentase penduduk miskin. Gambar 1 (b) memperlihatkan diagram pencar antara persentase penduduk miskin dengan angka melek huruf dan adanya hubungan linier negatif antara kedua variabel. Dengan nilai $p$-value tersebut dapat dikatakan bahwa terdapat korelasi yang signifikan antara kedua variabel, dapat diartikan sebagai semakin besar angka melek huruf maka semakin rendah persentase penduduk miskin.

Selanjutnya, pada Gambar 1(c) diperlihatkan diagram pencar antara persentase penduduk miskin dengan rasio banyaknya puskesmas dengan jumlah penduduk terlihat adanya hubungan linier negatif antara kedua variabel. Dengan nilai p-value tersebut dapat dikatakan bahwa korelasi antara kedua variabel tidak signifikan pada taraf nyata 5\%. Selain itu pada Gambar 1(d) memperlihatkan diagram pencar antara persentase penduduk miskin dengan pertumbuhan ekonomi. Dengan nilai 
p-value tersebut dapat dikatakan bahwa terdapat korelasi antara kedua variabel. Artinya semakin besar laju pertumbuhan produk domestik regional bruto atas dasar harga konstan 2010 maka semakin rendah persentase penduduk miskin.

\subsection{Pemilihan Model Estimasi Data Panel (Model 1)}

Sebelum melakukan estimasi, terlebih dahulu menentukan model regresi data panel yang sesuai sebagai metode estimasi.

Uji Chow (uji F) digunakan untuk menetukan apakah fixed effect model atau common effect model yang lebih tepat digunakan dalam mengestimasi data panel. Diperoleh perhitungan untuk uji Chow yaitu nilai $F_{\text {hitung }}=75,77094$ dan nilai $F_{18,34}=1,92644$. Nilai $F_{\text {hitung }}>F_{\text {tabel }}$ maka tolak $H_{0}$, artinya intersep untuk semua unit cross section tidak sama, sehingga metode yang tepat digunakan adalah fixed effect model.

Selanjutnya dilakukan uji Hausman untuk menentukan apakah fixed effect model atau random effect model yang lebih tepat digunakan dalam mengestimasi data panel. Hasilnya didapatkan nilai $p$-value sebesar 0,1368 lebih dari $\alpha=0,05$, ini berarti tidak tolak $H_{0}$. Dapat disimpulkan bahwa residual persamaan panel tidak berkorelasi dengan variabel bebas sehingga metode yang tepat digunakan adalah random effect model.

Langkah berikutnya adalah melakukan estimasi model dengan pendekatan Random effect model sebagai berikut :

$Y_{i t}=-2,026688-0,481199 X_{1 i t}+0,084255 X_{2 i t}+0,314481 X_{3}+0,215247 X_{4 i t}$

Dalam pengujian model regresi, ada beberapa tahap pengujian yang harus dilakukan yaitu Uji Signifikan Model (Uji F), Uji Signifikan Koefisien Regresi secara Parsial (Uji t).

Uji $F$ dilakukan untuk mengetahui pengaruh semua variabel prediktor terhadap variabel respon. Diperoleh perhitungan untuk uji $F$ yaitu $F_{\text {hitung }}=2,8575$ dan nilai $F_{4,52}=2,5497$. Sehingga nilai $F_{\text {hitung }}>F_{\text {tabel }}$ ini berarti tolak $H_{0}$, artinya minimal ada satu variabel prediktor yang berpengaruh secara signifikan terhadap variabel respon. Selanjutnya dilakukan uji parsial, yaitu untuk menguji bagaimana pengaruh masing-masing variabel prediktor secara sendiri-sendiri terhadap variabel respon. Hasil pengujian signifikansi model secara parsial ditampilkan pada tabel berikut :

Tabel 1. Tabel Uji Parsial

\begin{tabular}{|c|c|c|}
\hline Variabel Independen & label & p-value \\
\hline Persentase penduduk yang tamat SMA & $X_{1}$ & 0,0027 \\
Angka melek huruf & $X_{2}$ & 0,7035 \\
Rasio banyaknya puskesmas dengan jumlah penduduk & $X_{3}$ & 0,1304 \\
Pertumbuhan ekonomi & $X_{4}$ & 0,6127 \\
\hline
\end{tabular}

Berdasarkan tabel di atas dapat dilihat bahwa ada satu variabel berpengaruh secara signifikan terhadap persentase penduduk kemiskinan. Hal ini ditunjukkan dengan nilai $p$-value $<0,05$, yaitu variabel penduduk yang tamat $\operatorname{SMA}\left(X_{1}\right)$. 
Dari model yang diperoleh di atas, semakin besar persentase penduduk yang tamat SMA $X_{1}$ maka semakin rendah persentase penduduk miskin. Sebaliknya, jika semakin rendah persentase penduduk yang tamat SMA maka semakin tinggi persentase penduduk miskin.

\subsection{Pemilihan Model Estimasi Data Panel ( Model 2)}

Dari hasil pengujian yang dilakukan sebelumnya, $X_{1}$ berpengaruh. Akan dilakukan kembali Uji Chow dan Uji Hausman untuk menentukan model terbaik diantara CEM, FEM, dan REM, sehingga metode yang teoat digunakan adalah random effect model

\subsection{Interpretasi Model}

Dari analisis yang dilakukan, disimpulkan bahwa model terbaik adalah random effect model dan variabel yang signifikan berpengaruh adalah variabel penduduk yang tamat SMA $\left(X_{1}\right)$. Model regresi yang terbaik dapat dinyatakan sebagai berikut.

$$
\widehat{Y_{i t}}=9,4629-0,476081 X_{1 i t} \text {. }
$$

Dari model yang diperoleh di atas, semakin besar persentase penduduk yang tamat SMA $X_{1}$ maka semakin rendah persentase penduduk miskin. Sebaliknya, jika semakin rendah persentase penduduk yang tamat SMA maka semakin tinggi persentase penduduk miskin. Artinya bahwa semakin banyak penduduk yang tamat SMA, maka semakin besar peluang seseorang masuk ke dalam dunia kerja karena memiliki kemampuan atau pengetahuan yang besar. Selanjutnya akan dilakukan pengujian asumsi terhadap model terbaik yaitu model 2. Pada model 2 data tersebut tidak mengalami, dan tidak mengalami autokorelasi.

\section{Kesimpulan}

Berdasarkan hasil pengolahan data yang sudah dibahas pada bab pembahasan didapatkan model terbaik yaitu random effect model dengan terdapat satu variabel yang berpengaruh signifikan terhadap persentasi penduduk miskin yaitu persentase penduduk yang tamat SMA $X_{1}$. Semakin rendah persentase penduduk yang tamat SMA maka semakin tinggi persentase penduduk miskn. Sebaliknya, jika semakin tinggi persentase penduduk yang tamat SMA maka semakin rendah persentase penduduk miskin.

\section{Ucapan Terimakasih}

Terima kasih kepada Izzati Rahmi HG, M.Si, Dr. Maiyastri, dan Dr. Haripamyu yang telah memberikan kritik dan saran untuk penulisan artikel ini.

\section{Daftar Pustaka}

[1] Baltagi, B. H. 2008. Econometrics. Edisi ke-41. Verlag Berlin Heidelberg, Springer 
Faktor Kemiskinan dengan Analisis Regresi Panel 61

[2] Gujarati, D. N. 2003. Basic Econometrics. Mc Grwa Hill, Inc, New York

[3] Hsiao, C. 2003. Analysis of Panel Data. New York : Cambridge University Press

[4] Widarjono. 2007. Ekonometrika Teori dan Aplikasi untuk Ekonomi dan Bisnis. Ekonosia, Yogyakarta 